\title{
Environmental Features Formation of Algoflora Middle Flow Zarafshan River (Uzbekistan)
}

\author{
Y.Sh. Tashpulatov, \\ Samarkand State University, Samarkand, Uzbekistan \\ E-mail: yigitali_t1981@mail.ru \\ B.B. Kobulova \\ Tashkent Institute of Irrigation and Agricultural Mechanization Engineers. \\ Bukhara branch, Bukhara, Uzbekistan
}

\begin{abstract}
Algoflora of the Zarafshan River was formed by the integrated influence of environmental factors. The river is divided into 3 parts and this part is distinguished by a number of environmental factors such as the chemical composition of water, water temperature, transparency, flow rate, $\mathrm{pH}$, etc. 331 species were identified in the river algoflora and within the species taxon. The groups of algae are analyzed by the ratio of water temperature, by mineralization of water, by the habitat of algae, and indicator-saprobic species. Water temperatures are crucial for the distribution and development of algae. In the spring, 169 algal flora were identified, in the summer of 210, in the autumn of 13 and in the winter of 88 of algae. In the river algoflora, 16 eurythermal and 315 stenothermal algae species were established. Mineralization of river water varies from beta-oligagaline to alpha-oligogaline. The river waters are mainly freshwater and in some places less often fresh-brackish. This ensures the distribution of fresh-salt-water algae in the middle and lower parts of the river. The river algocenoses are distributed as follows: phytoplankton 62 , phytobenthos 134, phytoplankton-phytobenthos 66, periphyton 62 and epiphyte 7 int. From the river algoflora, 97 species and varieties of saprobic-indicator algae were identified. Using these species, the ecological and sanitary state of the river was determined. Indicator-saprobic algae is not evenly distributed over the seasons of the year.
\end{abstract}

Keywords. Environmental factors, taxa, eurytherm, stenotherm, freshwater, freshwater-salt-water, saltwater species, indicator-saprobic species, algocenoses.

DOI: $10.7176 / \mathrm{JSTR} / 6-07-09$

\section{Introduction}

Algae is the first link of the trophic chain, the main producer of organic matter in water bodies and the most promising object for assessing the state of aquatic ecosystems. An inventory of algoflora is relevant because the ecosystems of water bodies respond extremely quickly to changes in climatic and other physical and geographical conditions, as well as to the consequences of human activities. Qualitative and quantitative studies of algal communities are the main stage that opens the possibility for all subsequent work. In recent years, practical work in this area has been carried out in our republic and abroad.

The Zarafshan River is transboundary. The upper course begins with the Zarafshan glacier of mountain Tajikistan, the middle and lower course flows through the valley, which is located between the Zarafshan and Turkestan ranges of the Republic of Uzbekistan. The total length of the river reaches about $870 \mathrm{~km}$. The average length of the river is more than $200 \mathrm{~km}$ [1, p.126]. Algoflora of the middle course of the river. Zarafshan, saprobic - indicator species and its role in determining water quality has not been studied. Several channels, collectors, irrigation ditches, sewage from domestic and industrial branches flow along the river. This negatively affects the physicochemical composition of water and the biodiversity of the flora and fauna of the river. The middle course of the Zarafshan River begins from the village of Ravathuzha of the Urgut district of the Samarkand region to the village of Yangibazar of the Khatirchi district of the Navoi region $(200 \mathrm{~km})$. In this region, the population is more dense, industry is well developed, there are large cities near the river and well-developed irrigated agriculture.

Over the years of research, the taxonomic, floristic, comparative, ecological, and indicator - saprobic features of the algoflora of the middle reaches of the Zarafshan River have been studied. 


\section{Purpose of the study}

To study and justify the role of environmental factors in the formation of algoflora of the middle course of the Zarafshan River.

\section{Materials and research methods}

According to changes in environmental factors, water and the spread of polluting sources along the river are conventionally divided into 3 parts (upper, middle, lower). Conventionally, 10 observation posts were selected from parts of the river and algological samples were taken every month. During the sampling, the temperature of water and air was measured, the transparency of the water was determined using Secchi disk, water $\mathrm{pH}$-meter ( $\mathrm{pH} 340$ ), planktonic algae were collected by plankton networks Gas No. 76. To determine the species quantity, a Carl Zeiss microscope was used, micrometer eyepiece +7 , dyes. The following determinants were used: "The determinant of freshwater algae of the USSR" [2, p. 350; 3, p. $651 ; 4$, p. 248; 5, p. 619; 6, p.231; 7, p.778, 8, p.360], Ukrainian SSR [9, p.500; 10, p. 386] some determinants of Central Asia including Uzbekistan [11, p. 1215, 12, p. 283]. Changes made to the algal taxonomy were used in this work [13, p. 329-335; 14, p. 20]. Determination of algal saprobity was applied by the method of R. Kolkwitz, M. Marsson [15, s.113], G.I. Dolgov, Ya.Ya. Nikitinsky [16, p. 3-76] and V. Sladecek [17, s. 210-218], the saprobity index (Si) according to the formula of R. Pantle and N. Bukk [18, s.18-604], water quality, saprobity zone was determined by Zhukinsky et al. [19, p. 38-49].

\section{Results}

The study of algoflora of the middle course of the river. Zarafshan established 331 species and varieties of algae belonging to 5 departments (Cyanophyta, Bacillariophyta, Dinophyta, Euglenophyta, Chlorophyta). Of these, 97 species are ( 81 species, 13 variations, 3 form) indicator-saprobic species.

Temperature - the decisive role is the distribution and development of algae. Due to the increase in the temperature of water $\left(10-14^{\circ} \mathrm{S}\right)$ and air $\left(17-22^{\circ} \mathrm{S}\right)$, diatoms, green and blue-green algae are actively developing in spring. The most multi-species season in the middle reaches of the river. Zarafshan are in the summer. At this time of the year, the water temperature of the river reaches $22-26^{0} \mathrm{~S}$. All seasons, years and along the river currents, diatoms dominated, blue-green and green algae took the following place. Euglenae are found in spring, summer, and autumn, mainly in the middle and lower parts of the river. Pyrophytes were observed in spring and autumn along the entire course.

In autumn, the water temperature reaches $15-18^{0} \mathrm{~S}$, and the air $10-12^{0} \mathrm{~S}$. At this time of year, the number of species of blue-green, diatom, and green algae became less, and pyrophyte and euglena algae remained no change. The upper part of the river in winter had a water temperature of $1-2^{0} \mathrm{~S}$, and in the lower part it was $4-5^{\circ} \mathrm{S}$. The composition and species ratio of algae species sharply decreased. The heat-loving species of blue-green and green algae settles in the substrate and pass into dormancy. Pyrophyte and euglena are not found. In the spring, 169 (51.06\%) algae species were identified in algoflora, 210 $(63.44 \%)$ in the summer, $138(41.69 \%)$ in the autumn, and $88(26.59 \%)$ algae species and varieties in the winter (table 1).

Table 1.Algae distribution by seasons of the river algoflora

\begin{tabular}{|c|c|c|c|c|c|c|c|c|c|}
\hline Phylum algae & ڤ્) & $\%$ & 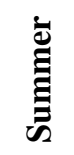 & $\%$ & 章 & $\%$ & 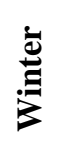 & $\%$ & $\stackrel{\bar{\sigma}}{\stackrel{5}{\theta}}$ \\
\hline Cyanoprocariota & 38 & 11,48 & 43 & 12,99 & 13 & 3,93 & 5 & 1,51 & 64 \\
\hline Bacillariophyta & 96 & 29,00 & 124 & 37,46 & 102 & 30,82 & 77 & 23,26 & 218 \\
\hline Dinophyta & - & - & 2 & 0,60 & 2 & 0,60 & - & - & 2 \\
\hline Euglenophyta & 7 & 2,11 & 10 & 3,02 & 10 & 3,02 & - & - & 10 \\
\hline Chlorophyta & 28 & 8,46 & 31 & 9,37 & 11 & 3,32 & 6 & 1,81 & 37 \\
\hline Total of 331: & 169 & 51,06 & 210 & 63,44 & 138 & 41,69 & 88 & 26,59 & 331 \\
\hline
\end{tabular}

Eurytherms are found all seasons of the year, and they can live a wide fluctuating temperature. Stenotherms live a narrower temperature range. And they meet a certain season of the year. In the algoflora of the middle course of the river. Zarafshan was found $16(4.83 \%)$ eurythermic and 315 $(95.17 \%)$ stenothermal species and varieties of algae (table 2 ). 
Table 2. Algae groups according to temperature ratio of river algoflora

\begin{tabular}{|c|c|c|c|c|c|}
\hline Phylum algae & eurytherms & $\mathbf{\%}$ & stenotherms & \% & total \\
\hline Cyanoprocariota & 4 & 1,21 & 62 & 18,73 & 64 \\
\hline Bacillariophyta & 10 & 3,02 & 208 & 62,84 & 218 \\
\hline Dinophyta & - & - & 2 & 0,60 & 2 \\
\hline Euglenophyta & - & - & 10 & 3,02 & 10 \\
\hline Chlorophyta & 2 & 0,60 & 35 & 10,57 & 37 \\
\hline Total of 331: & 16 & 4,83 & 315 & 95,17 & 331 \\
\hline
\end{tabular}

In the middle course of the river. Zarafshan the mineralization of water along the currents is increasing. In the beginning of the river, the average amount of minerals was 300.5-300.0 (max. 364.7-412) $\mathrm{mg} / \mathrm{l}$, near the city of Samarkand 284.9-292.6 (max. 356.9-381.9) $\mathrm{mg} / \mathrm{l}$, after the fall of the Siob collector, mineralization in the rivers increased to an average of 453.1-502.2 (max. 717.2-561.2) $\mathrm{mg} / \mathrm{l}$, and after the fall of the Taligul collector to an average of 344.4-403.7 (max. 680.0-687.1) mg/l, near the city of Kattakurgan (after the fall of the Chiganak collector) 468.2-537.5 (max. 729.1-750) mg/l, and in Hatirchi 593.8-662 8 ( $\max .907 .4-821.3) \mathrm{mg} / \mathrm{l}$. Mineralization of river water increases from alpha-hypogaline to beta-oligogaline. For some years (Khatirchi gyro-station - $907.4 \mathrm{mg} / \mathrm{l}$ ) the salinity of the river's water approached the brackish-water ones. Of the identified algae, 148 species $(44.71 \%)$ are freshwater, 160 $(48.34 \%)$ are freshwater-saline-water and $23(6.95 \%)$ are species and varieties of saline-water. Of these, 171 species are stenohaline, 160 species are euryhaline (table 3). From the middle parts of the river, water salinity was average $537.5-662.8 \mathrm{mg} / \mathrm{l}$, in the lower parts this amount is reached up to $907.4-821.3 \mathrm{mg} / \mathrm{l}$. Mineralization of water Zarafshan vary from beta-oligagaline to alpha-oligogaline. This ensures the distribution of fresh-salt-water algae in the middle and lower parts of the river.

Table 3. The relationship of algae to the water mineralization of the river algoflora

\begin{tabular}{|c|c|c|c|c|c|c|c|c|}
\hline Phylum algae & 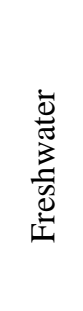 & 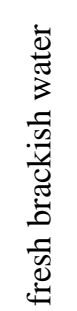 & 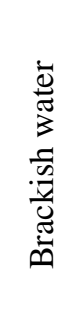 & $\stackrel{\pi}{0}$ & 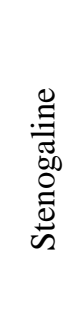 & $\begin{array}{l}\bar{Z} \\
\overline{0} \\
0 \\
0\end{array}$ & 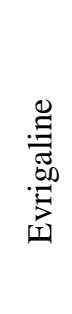 & $\begin{array}{l}\stackrel{0}{0} \\
\stackrel{\pi}{0} \\
0 \\
0\end{array}$ \\
\hline Cyanoprocariota & 23 & 40 & 1 & 64 & 24 & 14,03 & 40 & 25,00 \\
\hline Bacilllariophyta & 111 & 86 & 21 & 218 & 132 & 77,19 & 86 & 53,75 \\
\hline Euglenophyta & 1 & 9 & - & 10 & 1 & 0,58 & 9 & 5,62 \\
\hline Dinophyta & 1 & 1 & - & 2 & 1 & 0,58 & 1 & 0,63 \\
\hline Chlorophyta & 12 & 24 & 1 & 37 & 13 & 7,60 & 24 & 15,00 \\
\hline Total of 331: & 148 & 160 & 23 & 331 & 171 & 51,66 & 160 & 48,34 \\
\hline
\end{tabular}

From table 3 it is seen that the stenohaline species are larger than the euryhaline species. This is explained by the fact that the river's waters are mainly freshwater $(300-662.8 \mathrm{mg} / \mathrm{l})$ and in some places less often fresh-brackish-water (max. 907,4 mg/l).

The following river algocenoses are distributed: phytoplankton 62 (18.73\%), phytobenthos 134 (40.48\%), phytoplankton-phytobenthos $66(19.94 \%)$, periphyton $62(18.73 \%)$ and epiphyte $7(2.11 \%)$ species and varieties of algae (table 4). Due to the low transparency and high speed, the flow of water adversely affects the development of phytoplankton in the river. In such conditions, phytobenthos develop well. Some phytoplankton are also found in benthos. Places that have a strong periphyton flow develop abundantly. 
Table 4. Distribution by ecological group of river algoflora

\begin{tabular}{|c|c|c|c|c|c|c|c|c|c|c|c|}
\hline Phylum algae & 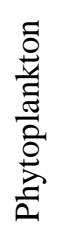 & $\delta^{\circ}$ & 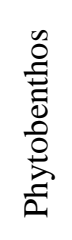 & se & 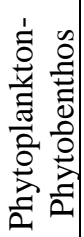 & 8 & 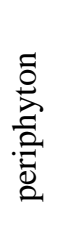 & 8 & 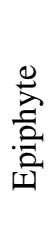 & $\delta^{0}$ & $\begin{array}{l}\text { స్త్ర } \\
\stackrel{0}{-1}\end{array}$ \\
\hline Cyanoprocariota & 12 & 3,63 & 28 & 8,46 & 24 & 7,25 & - & - & - & - & 64 \\
\hline Bacilllariophyta & 26 & 7,85 & 105 & 31,72 & 31 & 9,37 & 50 & 15,11 & 6 & 1,82 & 218 \\
\hline Euglenophyta & 6 & 1,82 & - & - & 4 & 1,21 & - & - & - & - & 10 \\
\hline Dinophyta & 2 & 0,60 & - & - & - & - & - & - & - & - & 2 \\
\hline Chlorophyta & 16 & 4,83 & 1 & 0,30 & 7 & 2,11 & 12 & 3,63 & 1 & 0,30 & 37 \\
\hline Total of 331: & 62 & 18,73 & 134 & 40,48 & 66 & 19,94 & 62 & 18,73 & 7 & 2,11 & 331 \\
\hline
\end{tabular}

Due to the hanging, the transparency of the river's water from the initial to the middle part of the river increases the number of phytoplankton species, but the transparency of the river's water still decreases in the lower part of the river. On account of this, the number of phytoplankton species decreases. Phytobenthos in the initial part of the river are 56 species, the middle 67, and at the lower part 46 species and varieties. Periphyton is found in stones, concretes and various substrates of the river bank and form a bloom of bright brown and ash color. Periphyton is distributed as follows: at the beginning of the river 23 species, middle 44, at the lower part 25 species and varieties. Ulothrix zonata is distributed throughout the currents, Cladophora glomerata, C. fracta, Chlorhormidium flaccidum, Ch. rivulare found lower part. The length of the thalli of these periphyton in the initial part of the river was $2-4 \mathrm{~cm}$, and in the lower part reached $11-17 \mathrm{~cm}$.

This is due to the fact that the lower parts of the river have low water flows $(0.55-0.25 \mathrm{~m} / \mathrm{s})$, minerals (593.5-662.8 mg/l) and nutrients $\left(\mathrm{NO}_{2} 1.17-2.11 \mathrm{mg} / \mathrm{l}\right)$ ) more than the initial part. In algoflora, 7 types of epiphytes were identified. Of these, 2 species are the initial part, 5 middle and 2 lower part. From the epiphytes Synedra ulna (Nitzsch) Ehr. found throughout the currents.

During the study, 97 species and varieties (81 rounds, 13 variations, 3 forms) of saprobic-indicator algae were identified from the river algoflora. This is $29.30 \%$ of the total algoflora. Distributed saprobic indicator species according to the departments of algae are shown in table 5.

Table 5. Distributed saprobic-indicator species by algal flora departments

\begin{tabular}{|c|c|c|c|c|c|c|c|c|c|}
\hline \multirow[b]{2}{*}{ Phylum algae } & \multirow[b]{2}{*}{$\frac{\tilde{E}}{\stackrel{\Xi}{U}}$} & \multirow[b]{2}{*}{ 过 } & \multirow[b]{2}{*}{ 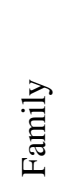 } & \multirow[b]{2}{*}{$\stackrel{\mathscr{\Xi}}{\circlearrowright}$} & \multicolumn{3}{|c|}{ species and varieties } & \multirow[b]{2}{*}{ total } & \multirow[b]{2}{*}{$\%$} \\
\hline & & & & & species & var. & form & & \\
\hline Cyanoprocariota & 2 & 3 & 8 & 8 & 8 & - & 2 & 10 & 10,30 \\
\hline Bacilllariophyta & 2 & 3 & 8 & 24 & 49 & 11 & 1 & 61 & 62,88 \\
\hline Euglenophyta & 1 & 1 & 1 & 1 & 1 & - & - & $\mathbf{1}$ & 1,03 \\
\hline Dinophyta & 1 & 1 & 1 & 2 & 9 & - & - & 9 & 9,27 \\
\hline Chlorophyta & 4 & 5 & 8 & 9 & 14 & 2 & - & 16 & 16,49 \\
\hline Total: & 10 & 13 & 26 & 44 & 81 & 13 & 3 & 97 & 100 \\
\hline
\end{tabular}

Of the 97 indicator-saprobic 20 (20.61\%) xenosaprobes, 18 (18.55\%) oligosaprobes, 51 (52.57\%) $\beta$ mesosaprobes, $5(5.15 \%) \alpha$-mesosaprobes, and 3 species and varieties ( $3.09 \%$ ) are polysaprobes (table 6). Indicator-saprobic algae is not evenly distributed over the seasons of the year. Of these, spring 56, summer 45, autumn 50 and winter 29 species and varieties. In the spring, the saprobity index was high (1.67), low in the winter (1.22), and in the summer (1.47) and autumn (1.52), intermediate results were 
observed. The saprobity boundary in spring was $\beta 1$-mesosaprob, and the remaining seasons were $\alpha$ oligosaprob. The average saprobity left 1, 47; $\beta$-oligosaprob (table 7).

Table 6. Distributions of indicator-saprobic species by departments of algal flora

\begin{tabular}{|c|c|c|c|c|c|c|c|}
\hline \multirow{2}{*}{ Phylum algae } & \multicolumn{5}{|c|}{ Number of indicator-saprobic species } & \multirow{2}{*}{$\begin{array}{c}\text { total } \\
\text { number }\end{array}$} & \multirow{2}{*}{$\%$} \\
\hline & $\mathrm{X}$ & o & $\beta$ & $\alpha$ & $\mathrm{p}$ & & \\
\hline Cyanoprocariota & 1 & 2 & 6 & 1 & - & 10 & 10.31 \\
\hline Bacilllariophyta & 17 & 14 & 28 & 2 & - & 61 & 62.89 \\
\hline Euglenophyta & - & 1 & - & - & - & 1 & 1,03 \\
\hline Dinophyta & 1 & 1 & 4 & 1 & 2 & 9 & 9.28 \\
\hline Chlorophyta & 1 & 1 & 12 & 1 & 1 & 16 & 16.49 \\
\hline Total: & 20 & 18 & 51 & 5 & 3 & 97 & \\
\hline$\%$ & 20,61 & 18,55 & 52,57 & 5,15 & 3,09 & & \\
\hline
\end{tabular}

Table 7. Saprobity index (Si) indicator-saprobic species by seasons of the year algoflora

\begin{tabular}{|c|c|c|c|c|c|c|c|c|}
\hline \multirow{2}{*}{ Phylum algae } & \multicolumn{2}{|c|}{ Spring } & \multicolumn{2}{|c|}{ Summer } & \multicolumn{2}{|c|}{ Autumn } & \multicolumn{2}{|c|}{ Winter } \\
\hline & $\mathrm{h}$ & $\mathrm{sh}$ & $\mathrm{h}$ & $\mathrm{sh}$ & $\mathrm{h}$ & $\mathrm{sh}$ & $\mathrm{h}$ & $\mathrm{sh}$ \\
\hline Cyanoprocariota & 23 & 43 & 28 & 52 & 3 & 6 & 0 & 0 \\
\hline Bacilllariophyta & 107 & 143 & 48 & 52 & 108 & 139 & 90 & 115 \\
\hline Euglenophyta & 0 & 0 & 3 & 3 & 3 & 3 & 0 & 0 \\
\hline Dinophyta & 20 & 42 & 29 & 60 & 29 & 60 & 0 & 0 \\
\hline Chlorophyta & 42 & 93 & 61 & 82 & 13 & 29 & 8 & 5 \\
\hline Number of species & \multicolumn{2}{|c|}{56} & \multicolumn{2}{|c|}{45} & \multicolumn{2}{|c|}{53} & \multicolumn{2}{|c|}{29} \\
\hline h; Sh & 192 & 321 & 169 & 249 & 156 & 237 & 98 & 120 \\
\hline $\mathrm{Si}$ & \multicolumn{2}{|c|}{1,67} & \multicolumn{2}{|c|}{1,47} & \multicolumn{2}{|c|}{1,52} & \multicolumn{2}{|c|}{1,22} \\
\hline
\end{tabular}

\section{Discussion}

Due to hanging, the fall of various organic substances into the rivers and lower temperatures increase the saprobity index of the river's water. In summer, the water temperature rises, at this time in algoflora the number of species of algae is 210 taxa. High temperature and activity of the sun's rays provide abundant oxygen production. This process accelerates the breakdown of organic substances. In results in water, organic matter is reduced. This leads to a decrease in indicator saprobic species (45) and saprobic index (169). In autumn, due to increased precipitation and a decrease in water temperature $\left(10-12^{0} \mathrm{~S}\right)$, an increase in the number of indicator-saprobic species and the saprobity index were observed. In winter, low water temperatures $\left(2-4^{0} \mathrm{~S}\right)$ limit the development of indicator-saprobic species. External environmental factors comprehensively affect the development and distribution of algoflora in the middle reaches of the Zarafshan River. The saprobity of water along the river is gradually increasing.

\section{References}

1. Schultz V.L., Mashrapov R. Hydrography of Central Asia. - Toshkent. 1969. -S. 226.

2. Gollerbach M.M., Polyansky V.I. Key to freshwater algae of the USSR. Vol. 1. The general part. Freshwater algae and their study. - M .: Soviet science, 1951. - S.350.

3. Gollerbach M.M., Kosinskaya E.K., Polyansky V.I. Key to freshwater algae of the USSR. Vol. 2. Blue-green algae. - M .: Soviet science, 1953. - S.651.

4. Vinogradova K.L., Gollerbach M.M., Sauer A.M., Sdobnikova N.V. Key to freshwater algae of the USSR. Vol. 13. Green algae- Chlorophyta: Classes Siphon storage, Siphon. Siphonocladophyceae, Siphonophyceae-Red Algae-Rhodophyta. Brown Algae-Phaeophyta. - L .: Science. Leningrad branch, 1980 .-- S. 248.

5. Zabelina M. M., Kiselev I. A., Proshkina-Lavrenko A. I., Scheshukova V. A., Key to freshwater algae of the USSR. Vol. 4. Diatoms. - M .: Soviet science, 1951. - P.619.

13. Kiselev I.A. Key to freshwater algae of the USSR. Vol. 6. Pyrophytic algae. - M .: Soviet science, 1954. - P.231. 
7. Kosinskaya E.K. Flora of spore plants of the USSR. T.V. Conjugates, or couplings (2) Desmidium algae. Vol. 1M.; L .: Publishing house of the Academy of Sciences of the USSR, 1960 .-- S. 778.

8. Moshkova N.O., Gollerbach M.M. Key to freshwater algae of the USSR. Vol. 10 (1). Green algae. Class Ulotrix. Chlorophyta: Ulothrichophyceae, Ulothrichales. - L .: Nauka, 1986. - P.360.

9. Moshkova N.O. Key to freshwater algae of the Ukrainian SSR. Vol. 6. Ulotrix and cladophore algae. - Kiev: Naukova Dumka, 1979. - P.500.

10. Matvienko O.M., Litvienko R.M. Key to freshwater algae of the Ukrainian SSR. Vol. 3. Part 2. Pyrophytes. - Kiev: Naukova Dumka, 1977. - P.386

11. Muzafarov AM, Ergashev AE, Khalilov S. Key to blue-green algae of Central Asia. Tashkent: Fan, Prince 1. -1987. - S. 405. Book. 2 1988. - S. 406-815. Book 3. 1988 .-- S. 816-1215.

12. Halilov S.A., Shoyakubov R.Sh., Temirov A.A., Kozirahimova N.K. Key to ulotrix algae of Uzbekistan. NCP "Botany" ANRUz. - Namangan. 2009 .-- P.283.

13. Wasser S.P., Kondratyeva N.V., Masiuk N.P., Palamar-Mordvintseva G.M. Vetrova Z.I., Kordyum E.L., Moshkova N.A., Prikhodkova L.P., Kovalenko O.V., Stupina V.V., Tsarenko P.M., Junger V.P., Radchenko M .I., Vinogradova O.N., Bukhtiyarova L.N., Razumina L.F. Algae: a reference. - Kiev: Naukova Dumka, 1989 .-- S. 329-335.

14. Zarei Darki B. Algae of water bodies of Iran // Abstr. Dr. Sci. (Biol.) Thesis. - Kiev, 2004 .-- R. 20.

15. Kolkwitz R., Marsson M. Oecologie der tierischen saprobien // Int. Rev. Hydrobiol., 1909. Vol. 11. - S. 113.

16. Dolgov G.I., Nikitinsky Y.Ya. Hydrobiological research methods // Sanitary research methods for drinking and wastewater. - M., 1927. - S. 3-76.

17. Sladecek V. System of water quality from the biological point of view // Arch. Hydrobiol. Erboeb. 1973. Bd. 7. - S. 210-218.

18. Pantle R., Buck N. Die biolodische Uberwachund der Gewasser und Darstellund der Ergebnisse // Gas-und Wasser-fash. 1955. Bd. 96. -S. 18-604.

19. Zhukinsky V.N., Oksiyuk O.P., Oleynik G.N., Koshelova S.I. Principles and experience in constructing an environmental classification of the quality of surface water of land // Gidrobiol. journal - Kiev, 1981 T.V. XVII. - No. 12. - S. 38-49. 